\title{
Ignicoccus gen. nov., a novel genus of hyperthermophilic, chemolithoautotrophic Archaea, represented by two new species, Ignicoccus islandicus sp. nov. and Ignicoccus pacificus sp. nov.
}

\author{
Harald Huber, Siegfried Burggraf, Thomas Mayer, Irith Wyschkony, \\ Reinhard Rachel and Karl O. Stetter
}

\begin{abstract}
Author for correspondence: Karl O. Stetter. Tel: +49941943 3160. Fax: +499419432403. e-mail: Karl.Stetter@biologie.uni-regensburg.de
\end{abstract}

Lehrstuhl für Mikrobiologie und Archaeenzentrum, Universität Regensburg, Universitätsstrasse 31, 93053 Regensburg, Germany
Two species of novel, chemolithoautotrophic, sulfidogenic micro-organisms were isolated from submarine hydrothermal systems in the Atlantic (at the Kolbeinsey Ridge north of Iceland) and in the Pacific (at $\left.9{ }^{\circ} \mathrm{N}, \mathbf{1 0 4}^{\circ} \mathrm{W}\right)$. The coccoid cells grew within a temperature range of $70-98^{\circ} \mathrm{C}$ (optimum around $90^{\circ} \mathrm{C}$ ). They gained energy by reduction of elemental sulfur using molecular hydrogen as the electron donor. 16S rDNA-based sequence comparisons revealed that the organisms are members of the crenarchaeal branch of the Archaea. They represent a new, deeply branching lineage within the family of the Desulfurococcaceae. In DNA-DNA hybridization experiments both strains exhibited low levels of hybridization to each other and to further representatives of this family. Therefore, they represent a new genus, for which the name Ignicoccus gen. nov. is proposed. At present it consists of two new species, Ignicoccus islandicus sp. nov. (type strain is Kol8 ${ }^{\top}=$ DSM $^{13165^{\top}}=$ ATCC $700957^{\top}$ ) and Ignicoccus pacificus sp. nov. (type strain is LPC $^{\top} 3^{\top}=$ DSM $^{\top}$ $1^{13166^{\top}}=$ ATCC $^{\mathbf{7}} \mathbf{A 0 9 5 8}^{\mathrm{T}}$ ).

Keywords: Archaea, Crenarchaeota, hyperthermophilic, marine, chemolithoautotrophic

\section{INTRODUCTION}

Within the Archaea, hyperthermophilic microorganisms growing optimally at temperatures between 80 and $110^{\circ} \mathrm{C}$ are found in both kingdoms, the Euryarchaeota and the Crenarchaeota (Stetter, 1988, 1996; Woese et al., 1990). Within the Euryarchaeota they are represented by deep-branching organisms like Methanopyrus kandleri and members of the genera Thermococcus, Pyrococcus, Methanothermus, Methanococcus and Archaeoglobus. So far, the cultivated Crenarchaeota are exclusively extremely thermophilic or hyperthermophilic (Huber \& Stetter, 1999). 16S rRNA-based sequence comparisons have revealed that three orders are evident within the Crenarchaeota (Burggraf et al., 1997): Sulfolobales,

The EMBL accession numbers for the 165 rDNA sequences of Ignicoccus islandicus and Ignicoccus pacificus are X99562 and AJ271794, respectively. consisting of lobed or coccoid-shaped thermoacidophiles, Thermoproteales, which harbours all rodshaped organisms of the kingdom, and the recently described order Desulfurococcales (Huber \& Stetter, 2000). Desulfurococcales is composed of two families: the Pyrodictiaceae, members of which grow optimally above $100{ }^{\circ} \mathrm{C}$, and the representatives of the Desulfurococcaceae, which exhibit optimal growth between 85 and $100{ }^{\circ} \mathrm{C}$ (Burggraf et al., 1997). The representatives of the Desulfurococcaceae are usually regular to irregular cocci, which occur singly or in pairs. Some species form chains or aggregates in addition. With the exception of the aerobic Aeropyrum pernix, all members of the Desulfurococcaceae are obligate anaerobes, growing heterotrophically by sulfur respiration of various organic compounds (producing $\mathrm{H}_{2} \mathrm{~S}$ ) or by fermentation. In both cases, yeast extract, peptides or sugars serve as substrates. Organic acids or alcohols are found as metabolic products (Huber \& Stetter, 1999). 
In this study we describe the isolation and properties of novel, chemolithoautotrophic members of the Desulfurococcaceae which grow by sulfur reduction with molecular hydrogen as electron donor.

\section{METHODS}

Sources of samples. At the Kolbeinsey Ridge, north of Iceland, eight samples of submarine sandy sediments and venting water (original temperatures around $90^{\circ} \mathrm{C}$ ) were taken by the research submersible 'Geo' at depths between 103 and $106 \mathrm{~m}$ (Fricke et al., 1989; Burggraf et al., 1990). Furthermore, black smoker samples were obtained during dive 3072 of the submersible 'Alvin' at the East Pacific Rise at $9^{\circ} \mathrm{N}, 104^{\circ} \mathrm{W}$ at a depth of $2500 \mathrm{~m}$. The samples were brought to our laboratory anaerobically without temperature control.

Strains and culture conditions. The new isolates were enriched and cultivated in strictly anaerobic half-strength SME medium (Stetter et al., 1983; Pley et al., 1991), prepared according to Balch \& Wolfe (1976). The medium contains the following components $\left(\mathrm{l}^{-1}\right)$ : $\mathrm{NaCl}, 13.85 \mathrm{~g} ; \mathrm{MgSO}_{4}$. $7 \mathrm{H}_{2} \mathrm{O}, \quad 3.5 \mathrm{~g} ; \quad \mathrm{MgCl}_{2} .6 \mathrm{H}_{2} \mathrm{O}, 2.75 \mathrm{~g} ; \mathrm{KH}_{2} \mathrm{PO}_{4}, 0.5 \mathrm{~g}$; $\mathrm{CaCl}_{2} .2 \mathrm{H}_{2} \mathrm{O}, 0.38 \mathrm{~g} ; \mathrm{KCl}, 0.33 \mathrm{~g} ;\left(\mathrm{NH}_{4}\right)_{2} \mathrm{SO}_{4}, 0.25 \mathrm{~g}$; $\mathrm{NaBr}, 0.05 \mathrm{~g} ; \mathrm{H}_{3} \mathrm{BO}_{3}, 0.015 \mathrm{~g} ; \mathrm{SrCl}_{2} .6 \mathrm{H}_{2} \mathrm{O}, 7.5 \mathrm{mg}$; KI $\left(1 \mathrm{mg} \mathrm{ml}^{-1}\right), 25 \mu \mathrm{l}$; elemental sulfur, $5 \cdot 0 \mathrm{~g}$. Reduction of the medium was carried out by addition of $20 \mathrm{ml} \mathrm{Na}_{2} \mathrm{~S}(2.5 \%$, $\mathrm{w} / \mathrm{v})$; afterwards, the $\mathrm{pH}$ was adjusted at room temperature to 5.5 with sulfuric acid. The organisms were grown routinely in $120 \mathrm{ml}$ serum bottles containing $20 \mathrm{ml}$ medium pressurized with $\mathrm{H}_{2} / \mathrm{CO}_{2}(80: 20, \mathrm{v} / \mathrm{v} ; 250 \mathrm{kPa})$. Incubation was carried out at $90^{\circ} \mathrm{C}$ with shaking (100 r.p.m.). Heterotrophic growth was tested under a gas phase of $\mathrm{N}_{2} / \mathrm{CO}_{2}(80: 20, \mathrm{v} / \mathrm{v}$; $200 \mathrm{kPa})$.

Unless otherwise stated, organic substrates and alternative electron acceptors (thiosulfate, sulfite, sulfate, nitrate and nitrite) were added at final concentrations of $0.1 \%$. Batch cultures were grown in a 3001 enamel-protected fermenter (HTE Bioengineering) at $90{ }^{\circ} \mathrm{C}$ with stirring (100 r.p.m.) and gassing with $\mathrm{H}_{2} / \mathrm{CO}_{2}\left(80: 20 ; 21 \mathrm{~min}^{-1}\right)$.

Light and electron microscopy. Cells were routinely observed with an Olympus BX 60 phase-contrast microscope with an oil immersion objective, UPlanFl 100/1·3. Bacterial growth was followed by direct cell counting using a Thoma chamber (depth $0.02 \mathrm{~mm}$ ). Electron microscopy was performed as follows. For direct visualization, cells were chemically fixed by adding glutaraldehyde $(2 \%, \mathrm{v} / \mathrm{v}$, final concn $)$ to the culture medium, concentrated by centrifugation, applied onto a carbon-coated copper grid and shadowed with $1 \mathrm{~nm} \mathrm{Pt} / \mathrm{C}\left(\right.$ angle $15^{\circ}$ ). For ultrathin sections, cells were cultivated in cellulose capillary tubes, high-pressure frozen, freeze-substituted in acetone containing $1 \% \mathrm{OsO}_{4}$ and embedded in Epon/Araldite (Rieger et al., 1997). Sections were stained with uranyl acetate and lead citrate. For freezeetching, a concentrated cell suspension was frozen in liquid nitrogen, freeze-etched for $4 \mathrm{~min}$ at $-97^{\circ} \mathrm{C}$ and shadowed with $1 \mathrm{~nm} \mathrm{Pt} / \mathrm{C}\left(\right.$ angle $45^{\circ}$ ) and with $10 \mathrm{~nm} \mathrm{C}$ (angle $90^{\circ}$ ). Replicas were cleaned overnight on sulfuric acid $(70 \%$, $\mathrm{w} / \mathrm{v})$. Electron micrographs were taken on a model CM12 transmission electron microscope (Philips) with an acceleration voltage of $120 \mathrm{kV}$.

$\mathrm{H}_{2} \mathrm{~S}$ determination. The formation of $\mathrm{H}_{2} \mathrm{~S}$ was qualitatively monitored by addition of $20 \mu \mathrm{l}$ saturated lead acetate solution to $0.5 \mathrm{ml}$ samples, yielding a dark brown precipitate.
For quantitative determinations, $\mathrm{H}_{2} \mathrm{~S}$ was analysed by titration (Williams et al., 1979).

Lipid analysis. Core lipids were analysed according to Trincone et al. (1992).

DNA isolation and DNA base composition. DNAs were prepared as described previously (Wildgruber et al., 1982). The $\mathrm{G}+\mathrm{C}$ content of genomic DNAs was determined by melting point analysis (Marmur \& Doty, 1962) and by direct analysis of the nucleotides after digestion of the DNA with nuclease P1 and separation by HPLC chromatography (Völkl et al., 1993). Calf thymus DNA was used as reference.

DNA-DNA hybridization. DNA-DNA hybridization was carried out using the filter technique (Gillespie \& Gillespie, 1971; Birnstiel et al., 1972) as described by Pley et al. (1991). Nucleic acids were hybridized under optimal conditions $\left(25^{\circ} \mathrm{C}\right.$ below $T_{\mathrm{M}}$ in $3 \times \mathrm{SSC}$ buffer at $65^{\circ} \mathrm{C}$ ) (Marmur \& Doty, 1961; Brenner, 1973; Meyer \& Schleifer, 1978) using the DNAs of $\mathrm{Kol}^{\mathrm{T}}$ and $\mathrm{LPC} 33^{\mathrm{T}}$ as probes.

16S rRNA analysis. The nearly complete $16 \mathrm{~S}$ rRNA genes of the new isolates were PCR-amplified (Saiki et al., 1985, 1988). The primers used in the amplification corresponded to positions 8-23 (TCYGGTTGATCCTGCC), and 1512-1492 (ACGGHTACCTTGTTACGACTT) for Kol8 ${ }^{\mathrm{T}}$ or 1406-1390 (ACGGGCGGTGTGTRCAA) for LPC strains (Escherichia coli 16S rRNA numbering; Brosius et al., 1981). Both strands of the PCR products were directly sequenced as described by Burggraf et al. (1997). The sequences $\left(\mathrm{Kol}^{\mathrm{T}}, 1465\right.$ bases; LPC $33^{\mathrm{T}}$, 1311 bases; LPC37, 1297 bases) were aligned with a set of representative archaeal sequences using the ARB program (W. Ludwig \& O. Strunk, 1998, http://www.mikro.biologie.tu-muenchen.de/pub/ ARB/). Dendrograms were computed with the neighbourjoining, maximum-parsimony and maximum-likelihood methods included in the ARB package.

\section{RESULTS}

\section{Enrichment and isolation}

To enrich chemolithoautotrophic, sulfur-reducing hyperthermophiles, serum bottles with $20 \mathrm{ml}$ halfstrength SME medium supplemented with $1 \%(\mathrm{w} / \mathrm{v})$ sulfur (gas phase $\mathrm{H}_{2} / \mathrm{CO}_{2}$ ) were inoculated with about $1 \mathrm{~g}$ of the sandy sediments from the Kolbeinsey Ridge or rocky black smoker material obtained from the deep sea of the East Pacific Rise. The enrichment attempts were incubated with shaking at $90{ }^{\circ} \mathrm{C}$. After $2 \mathrm{~d}$, irregular cocci had grown in 3 out of 10 samples $\left(\mathrm{Kol}^{\mathrm{T}}, \mathrm{LPC}^{3} 3^{\mathrm{T}}\right.$ and LPC 37) and large amounts of $\mathrm{H}_{2} \mathrm{~S}$ could be detected qualitatively in the culture medium. The enrichment cultures were successfully transferred into fresh medium and cells were first purified by serial dilution carried out three times using the same medium. In addition, the 'optical tweezer' technique was used for final purification (Huber et al., 1995). The isolates were designated as the samples.

\section{Morphology}

Cells of both new isolates were irregular cocci usually occurring singly or in pairs. They exhibited cell diameters between 1.2 and $3 \mu \mathrm{m}\left(\mathrm{Kol}^{\mathrm{T}}\right)$, and 1 and 
$2 \mu \mathrm{m}\left(\right.$ LPC $\left.33^{\mathrm{T}}\right)$. The organisms stained Gram-negative. They were both motile, possessing one bundle of up to nine flagella (for isolate $\mathrm{Kol}^{\mathrm{T}}$; Fig. 1a). The cell architecture of the isolates was studied by sectioning cells after high-pressure freezing and freeze-substitution (Fig. 1b) and by the freeze-etch/freeze-fracture technique (Fig. 1c). The cytoplasm was densely packed and surrounded by a membrane (approx. 6-8 $\mathrm{nm}$ wide). The periplasm had a variable width, ranging between $20 \mathrm{~nm}$ and $350 \mathrm{~nm}$. It contained numerous, round or elongated vesicles, $50-60 \mathrm{~nm}$ in diameter and up to $300 \mathrm{~nm}$ in length, each surrounded by a membrane (Fig. 1b). Rarely, these periplasmic vesicles were in close contact with the cytoplasmic membrane. In sections, the outermost part of the cell envelope occasionally had a weak double-layer appearance. This 'sheath' was frequently found to be fractured into two leaflets in freeze-etch/freeze-fracture experiments (Fig. 1c) and, therefore, most likely represented a (lipid) membrane. Close inspection of the fracture planes revealed that this membrane was tightly packed with particles, most likely proteins. A two-dimensional crystalline arrangement, as observed in S-layer sheets of most Archaea and many Bacteria, was never observed. The core lipids of isolate $\mathrm{Kol}^{\mathrm{T}}$ are acyclic 2,3-di- $O$-phytanyl-sn-glycerol and glyceroldialkyl glycerol tetraether in a relative ratio of about 1:1 (A. Gambacorta, personal communication).

\section{Metabolism}

The new isolates were obligate anaerobes, growing chemolithoautotrophically by sulfur reduction using molecular hydrogen as electron donor (final cell concentrations up to $4 \times 10^{7}$ cells ml ${ }^{-1}$ ). Up to $25 \mu \mathrm{mol}$ $\mathrm{H}_{2} \mathrm{~S}$ (ml culture medium) ${ }^{-1}$ was formed by isolate $\mathrm{Kol}^{\mathrm{T}}$ at the end of the exponential growth phase. In the presence of $\mathrm{H}_{2}$ and $\mathrm{S}^{\circ}$, growth of all isolates was stimulated by the addition of meat extract, tryptone and glycogen (each $0 \cdot 1 \%$; final cell densities around $6 \times 10^{7}-8 \times 10^{7}$ cells $\left.\mathrm{ml}^{-1}\right)$. The addition of yeast extract $(0 \cdot 1 \%)$ resulted in shorter doubling times for both strains, although higher final cell densities were only observed for $\mathrm{LPC} 33^{\mathrm{T}}$. No effect on growth or final cell concentrations was obtained in the presence of Casamino acids, casein, starch, gelatin, maltose or glucose (each $0 \cdot 1 \%$ ) for all strains. The addition of formate or acetate $(0.05 \%)$ decreased final cell densities to about $1 \times 10^{7}$ cells $\mathrm{ml}^{-1}$. No growth was observed on organic substrates like meat extract, yeast extract, peptone, Casamino acids, gelatin, starch, formate, acetate or glucose when cultures were pressurized with hydrogen-free gas $\left(\mathrm{N}_{2} / \mathrm{CO}_{2}, 80: 20\right.$; $200 \mathrm{kPa}$ ). In a similar way, sulfur could not be replaced by oxygen $(0.5-5 \% \mathrm{v} / \mathrm{v})$, thiosulfate, tetrathionate, sulfite, sulfate or nitrate (each $0 \cdot 1 \%$ ) as electron acceptors. Ampicillin, rifampicin and vancomycin (final concn $50 \mu \mathrm{g} \mathrm{ml}^{-1}$ ) were not inhibitory to growth of the strains.

\section{Optimal growth conditions}

Isolate $\mathrm{Kol} 8^{\mathrm{T}}$ grew between 70 and $98^{\circ} \mathrm{C}$. No growth was observed at $65^{\circ} \mathrm{C}$ or below, nor at $100{ }^{\circ} \mathrm{C}$ or above (Fig. 2). Isolates LPC $33^{\mathrm{T}}$ and LPC 37 were able to grow between 75 and $98^{\circ} \mathrm{C}$ with an optimum at $90{ }^{\circ} \mathrm{C}$ (Fig. 2 ). When the medium was supplemented with $0 \cdot 1 \%$ meat extract, the shortest doubling times of 1.4 and $0 \cdot 8 \mathrm{~h}$ were observed for isolates $\mathrm{Kol}^{\mathrm{T}}$ and $\mathrm{LPC} 33^{\mathrm{T}}$ at $90{ }^{\circ} \mathrm{C}$, respectively (Fig. 2). Under chemolithoautotrophic conditions, the shortest doubling times were 1.7 and $1.6 \mathrm{~h}$ at $90{ }^{\circ} \mathrm{C}$, respectively (data not shown). $\mathrm{Kol}^{\mathrm{T}}$ grew at $\mathrm{NaCl}$ concentrations between 0.3 and $5.5 \%(\mathrm{w} / \mathrm{v})$ (Fig. 3), while strain LPC $33^{\mathrm{T}}$ exhibited a minimum $\mathrm{NaCl}$ requirement of $1.0 \%$ and a maximum of $5.0 \%$ (Fig. 3). For all strains the optimal $\mathrm{NaCl}$ concentration was around $2 \%$ and cells lysed at $\mathrm{NaCl}$ concentrations above $6.0 \%$ in the medium. Kol $8^{\mathrm{T}}$ grew between $\mathrm{pH} 3.8$ and 6.5 with an optimum around pH 5.8 (Fig. 4). The optimal pH for growth of LPC $33^{\mathrm{T}}$ was 6.0 with a minimum at $\mathrm{pH} 4.5$ and a maximum at pH 7.0 (Fig. 4).

\section{Storage}

Stock cultures, containing $5 \%$ (v/v) dimethylsulfoxide and stored at $-140{ }^{\circ} \mathrm{C}$ over liquid nitrogen served as viable inocula for at least 3 years.

\section{DNA base composition}

The $\mathrm{G}+\mathrm{C}$ content of genomic DNA of isolate $\mathrm{Kol} 8^{\mathrm{T}}$ was $41 \mathrm{~mol} \%$, calculated by melting point analysis and by direct analysis of the mononucleotides. Isolates LPC $33^{\mathrm{T}}$ and LPC 37 exhibited $45 \mathrm{~mol} \% \mathrm{G}+\mathrm{C}$ in their genomic DNA.

\section{DNA-DNA similarity}

DNA-DNA hybridization experiments revealed no significant hybridization signals between isolate $\mathrm{Kol}^{\mathrm{T}}$ and isolates $\mathrm{LPC}^{3} 3^{\mathrm{T}}$ and LPC37 (similarity 11 and $8 \%$, respectively). In contrast, a DNA-DNA similarity of $76 \%$ was obtained between $\mathrm{LPC}^{\mathrm{T}} 3^{\mathrm{T}}$ and LPC37. The DNA of each of the new isolates yielded no significant hybridization signal (similarity between 5 and $9 \%$ ) with DNA of the following Crenarchaeota and Euryarchaeota: Staphylothermus marinus, Desulfurococcus mobilis, Thermococcus celer and Pyrococcus furiosus.

\section{Phylogenetic analysis}

Comparison of 16S rDNA sequences between the new isolates and representatives of the Crenarchaeota and Euryarchaeota using all three major approaches for tree reconstruction clearly indicated that the new 

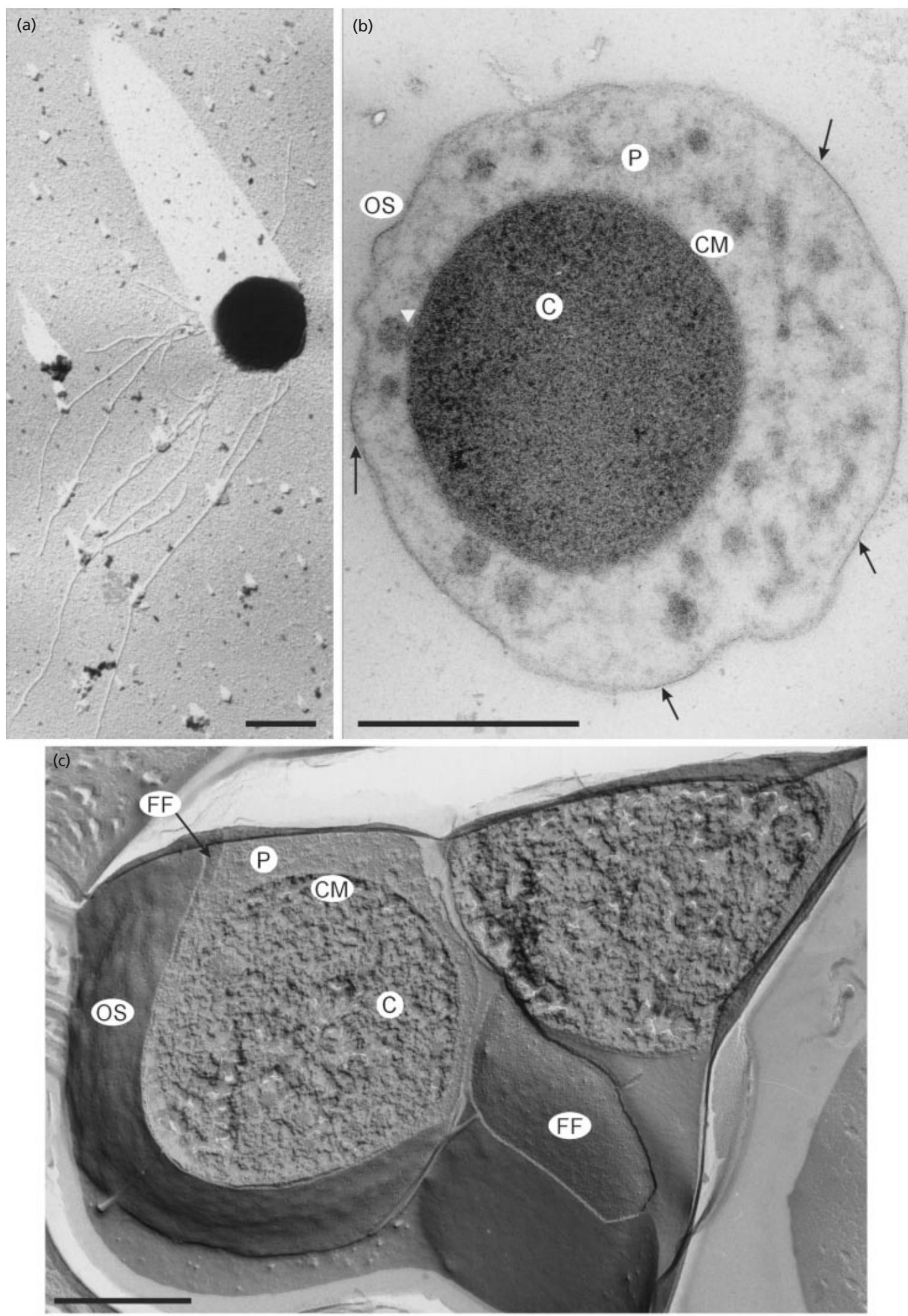

Fig. 1. For legend see facing page. 


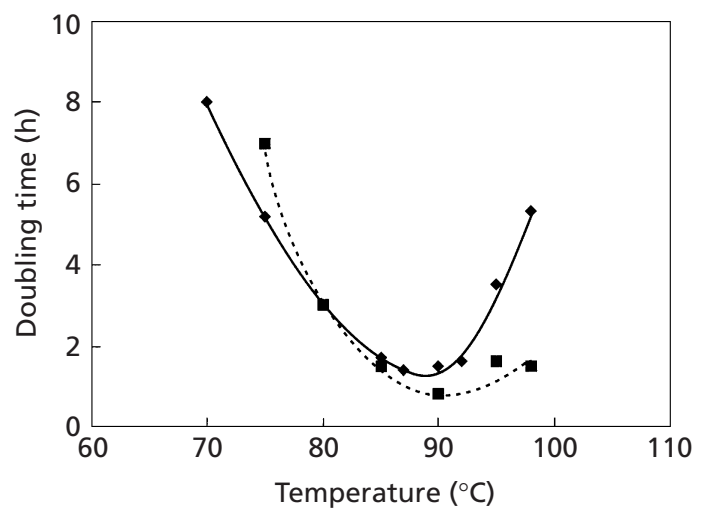

Fig. 2. Optimal growth temperature of Ignicoccus islandicus strain $\mathrm{Kol}^{\top}(\diamond)$ and Ignicoccus pacificus strain $\mathrm{LPC}^{\top} 3^{\top}(\mathbf{\square})$ during growth on $\mathrm{H}_{2}$ and sulfur at $\mathrm{pH} 5.5$ and $2 \% \mathrm{NaCl}$. Doubling times were calculated from the slopes of the growth curves (not shown).

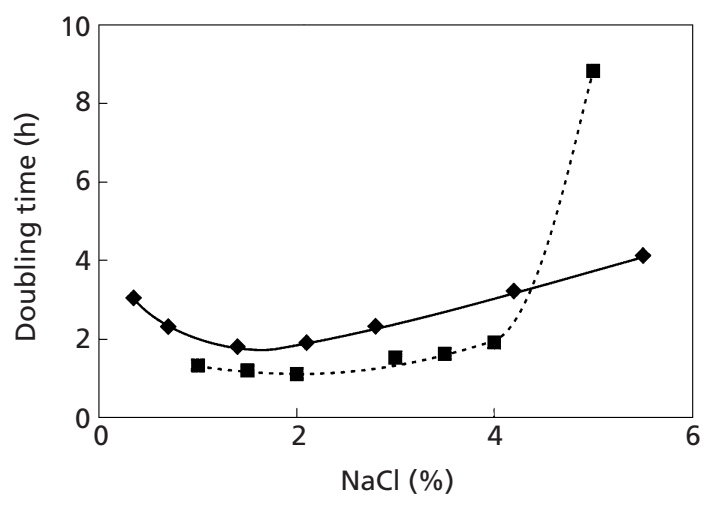

Fig. 3. Effect of $\mathrm{NaCl}$ concentration on growth of Ignicoccus islandicus strain $\mathrm{Kol}^{\top}(\diamond)$ and Ignicoccus pacificus strain $\mathrm{LPC}^{\top} 3^{\mathrm{T}}$ (a) at $90^{\circ} \mathrm{C}$ and $\mathrm{pH} 5.5$. Doubling times were calculated as described in the legend to Fig. 2.

strains belong to the crenarchaeal branch of the archaeal domain (Fig. 5). In all calculations they are members of the new order Desulfurococcales, representing a deep branch within the Desulfurococcaceae (Fig. 5). They exhibit sequence differences between 6 and $10 \%$ to any of the other members of this family (data not shown). In contrast, the differences among the new isolates were between $0 \cdot 2\left(\mathrm{LPC} 33^{\mathrm{T}}\right.$ and LPC 37$)$ and $2.0 \%\left(\mathrm{Kol}^{\mathrm{T}}\right.$ and LPC strains).

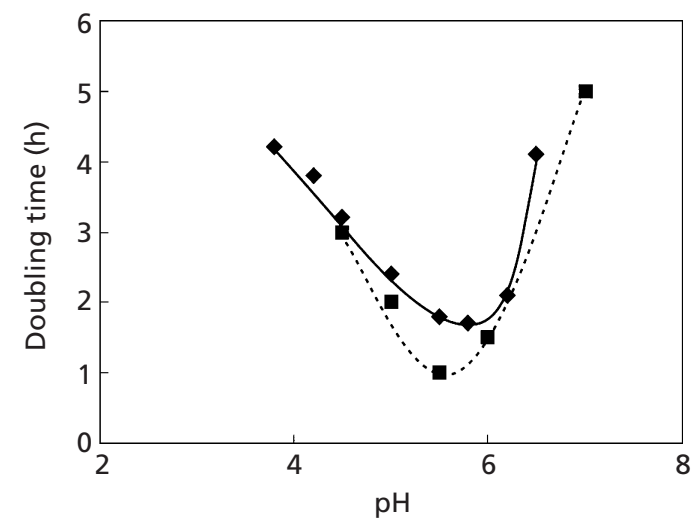

Fig. 4. Effect of $\mathrm{pH}$ on growth of Ignicoccus islandicus strain $\mathrm{Kol}^{\top}(\diamond)$ and Ignicoccus pacificus strain $\mathrm{LPC}^{\top} 3^{\top}(\boldsymbol{\square})$ at $90^{\circ} \mathrm{C}$ and $2 \% \mathrm{NaCl}$. Doubling times were calculated as described in the legend to Fig. 2.

\section{DISCUSSION}

The novel hyperthermophilic isolates $\mathrm{Kol}^{\mathrm{T}}$, $\mathrm{LPC}^{3} 3^{\mathrm{T}}$ and LPC37 represent the first obligate chemolithoautotrophic sulfur reducers within the crenarchaeal family of the Desulfurococcaceae. They are representatives of this family due to their coccoid cell shape, the lack of a cell sacculus, their negative Gram reaction, their optimal growth temperature of around $90{ }^{\circ} \mathrm{C}$ and their $16 \mathrm{~S}$ rDNA sequences (Huber \& Stetter, 2000). They can be differentiated from the other members of the Desulfurococcales by their unique cell wall architecture (Baumeister \& Lembcke, 1992) and the extremely limited spectrum of utilized electron donors and acceptors: molecular hydrogen is the only electron donor and no acceptors other than elemental sulfur can be used. Therefore, the organisms are obligate hydrogen-sulfur autotrophs, producing $\mathrm{H}_{2} \mathrm{~S}$. Some organic components stimulate growth by decreasing the shortest doubling times and yielding higher final cell densities. However, they cannot be used as sole energy sources. In contrast, all other anaerobic members of the Desulfurococcaceae known so far grow organotrophically. In addition to organic acids or alcohols, several representatives produce $\mathrm{H}_{2} \mathrm{~S}$ from elemental sulfur (e.g. Desulfurococcus, Staphylothermus, 'Thermodiscus' or Stetteria), while the members of the genera Sulfophobococcus and Thermosphaera are inhibited in the presence of elemental sulfur (Huber \& Stetter, 1999). This physiological separateness of the new isolates is confirmed by $16 \mathrm{~S}$ rDNA sequence analyses, where the new isolates

Fig. 1. (a) Electron micrograph of a cell of isolate $\mathrm{Kol}^{\top}$, exhibiting numerous flagella. The sample was fixed with $2 \%$ glutaraldehyde and shadowed with Pt/C. Bar, $1 \mu \mathrm{m}$. (b) Electron micrograph of a thin section of a freeze-substituted cell of isolate $\mathrm{Kol}^{\top}{ }^{\top}$. C, cytoplasm; CM, cytoplasmic membrane; $\mathrm{P}$, periplasm; OS, outer sheath; white arrowhead, contact site of a periplasmic vesicle with the cytoplasmic membrane; black arrows, areas of the outer sheath with double-layer appearance. Bar, $0.5 \mu \mathrm{m}$. (c) Electron micrograph of freeze-etched cells of isolate Kol8 $8^{\top}$. C, cytoplasm; CM, cytoplasmic membrane; P, periplasm; FF, fracture face of the outer sheath; OS, outer sheath. Bar, $0.5 \mu \mathrm{m}$. 


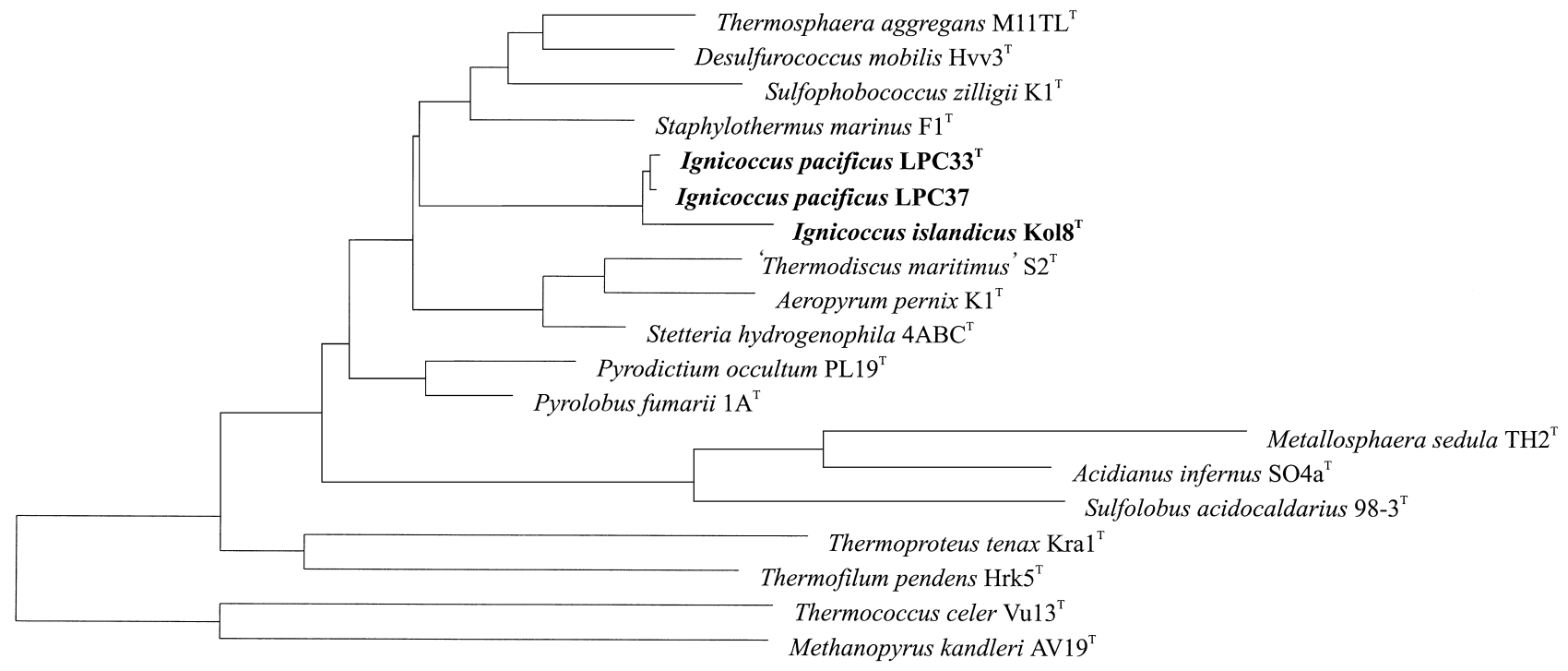

0.10

Fig. 5. Phylogenetic position of Ignicoccus species (isolates Kol8 ${ }^{\top}, \mathrm{LPC}^{\top} 3^{\top}$ and $\mathrm{LPC} 37$ ), calculated by the neighbour-joining method using Jukes \& Cantor correction. Bar, 10 estimated substitutions per $100 \mathrm{nt}$.

exhibit sequence differences of at least $6 \%$ to any other representative of the Desulfurococcaceae but only about $2 \%$ to each other. This indicates that the new isolates belong to the same new genus, for which we propose the name Ignicoccus gen. nov., the 'fireball', expressing the extremely high temperature optimum of all strains. The first isolate, $\mathrm{Kol}^{\mathrm{T}}$, can be distinguished from the two LPC strains by a generally bigger cell diameter, a lower minimum growth temperature of $70{ }^{\circ} \mathrm{C}$, growth at lower $\mathrm{NaCl}$ concentrations $(0.3 \%$ in contrast to $1.0 \%$ ), a low DNA-DNA similarity to these two organisms and a $4 \mathrm{~mol} \%$ lower genomic DNA $\mathrm{G}+\mathrm{C}$ content. It represents the type species of the new genus, which we have named Ignicoccus islandicus (type strain is $\mathrm{Kol}^{\mathrm{T}}=\mathrm{DSM} 13165^{\mathrm{T}}=$ ATCC $700957^{\mathrm{T}}$ ), referring to the location of its isolation.

Isolates LPC $33^{\mathrm{T}}$ and LPC37 show similar physiological and molecular characteristics. Furthermore, in DNA-DNA hybridization experiments, a similarity of $76 \%$ was obtained for these two organisms. This indicates that they belong to the same second species, which we have named Ignicoccus pacificus, referring to the location of its isolation. The type strain is LPC $33^{\mathrm{T}}$ $\left(=\right.$ DSM $13166^{\mathrm{T}}=$ ATCC $\left.700958^{\mathrm{T}}\right)$.

Ignicoccus islandicus and Ignicoccus pacificus were isolated from hot sediments at the Kolbeinsey Ridge, north of Iceland, and from active black smoker walls from the East Pacific, respectively. These biotopes are located far from each other and represent different geological environments. Therefore, since their substrates (hydrogen, $\mathrm{CO}_{2}$ and sulfur) are commonly found in hydrothermal fluids (Jannasch \& Mottl, 1985), representatives of Ignicoccus may be widely distributed in submarine hydrothermal systems. Due to their chemolithoautotrophic mode of life, they are probably important primary producers of organic matter in these biotopes and are essential for the growth of organotrophic hyperthermophiles, like the other marine representatives of the Desulfurococcaceae.

\section{Description of Ignicoccus gen. nov. (Huber, Burggraf and Stetter)}

Ignicoccus (Ig'ni.coc'cus. L. masc. n. ignis fire; Gr. masc. n. coccos berry; M.L. masc. n. Ignicoccus the berry of the fire).

Irregular cocci, about $1-3 \mu \mathrm{m}$ in diameter, monopolar polytrichous flagella. Gram-negative. Occurring singly and in pairs. Cell envelope consists of a cytoplasmic membrane, a periplasm (20-350 nm wide) and a sheath resembling an outer membrane. Cells contain phytanyl di- and tetraether lipids. Growth between 70 and $98^{\circ} \mathrm{C}, \mathrm{pH}$ optimum around 6. Strictly anaerobic. Chemolithoautotrophic growth in the presence of $\mathrm{H}_{2}$ and $\mathrm{CO}_{2}$ with sulfur as electron acceptor. Sulfate, sulfite, thiosulfate, tetrathionate, nitrate and oxygen are not used as electron acceptors. $\mathrm{H}_{2} \mathrm{~S}$ formed during growth. Ampicillin-, rifampicin- and vancomycinresistant. DNA base composition between 41 and $45 \mathrm{~mol} \% \mathrm{G}+\mathrm{C}$. Based on $16 \mathrm{~S}$ rDNA sequence comparison, the genus is a member of the family Desulfurococcaceae, within the kingdom Crenarchaeota. Type 
species is Ignicoccus islandicus $\left(\mathrm{Kol}^{\mathrm{T}}=\mathrm{DSM} 13165^{\mathrm{T}}\right.$ $=$ ATCC $700957^{\mathrm{T}}$ ).

\section{Description of Ignicoccus islandicus sp. nov. (Huber, Burggraf, Mayer and Stetter)}

Ignicoccus islandicus (is.lan'di.cus. M.L. masc. adj. islandicus Icelandic, pertaining to the location of its first isolation).

Slightly irregular cocci, about $1 \cdot 2-3 \mu \mathrm{m}$ in diameter, monopolar polytrichous flagella. Gram-negative. Occurring singly and in pairs. No evidence for a regular arrayed surface protein. Growth between 70 and $98^{\circ} \mathrm{C}$, $\mathrm{pH} 3 \cdot 8-6.5$ and $0.3-5.5 \% \mathrm{NaCl}$; optima are $90{ }^{\circ} \mathrm{C}$, $\mathrm{pH} 5.8$ and $2 \% \mathrm{NaCl}$. Strictly anaerobic. Chemolithoautotrophic growth in the presence of $\mathrm{H}_{2}$ and $\mathrm{CO}_{2}$ with sulfur as electron acceptor. No chemo-organotrophic growth on meat extract, yeast extract, peptone, Casamino acids, gelatin, starch, formate, acetate and glucose. Sulfate, sulfite, thiosulfate, nitrate and oxygen are not used as electron acceptors. $\mathrm{H}_{2} \mathrm{~S}$ (up to $25 \mu \mathrm{mol} \mathrm{m}{ }^{-1}$ ) is formed during growth. Growth stimulated by addition of $0 \cdot 1 \%$ meat extract, tryptone or gelatin. DNA base composition $41 \mathrm{~mol} \% \mathrm{G}+\mathrm{C}$. Low DNA-DNA similarity to Ignicoccus pacificus. Type strain is isolate $\mathrm{Kol}^{\mathrm{T}}\left(=\mathrm{DSM} 13165^{\mathrm{T}}=\mathrm{ATCC}\right.$ $700957^{\mathrm{T}}$ ), isolated from the Kolbeinsey Ridge, north of Iceland.

\section{Description of Ignicoccus pacificus sp. nov. (Huber and Stetter)}

Ignicoccus pacificus (pa.ci'fi.cus. M.L. masc. adj. pacificus from the Pacific, pertaining to the site of its first isolation).

Slightly irregular cocci, about $1-2 \mu \mathrm{m}$ in diameter, monopolar polytrichous flagella. Gram-negative. Occurring singly and in pairs. No evidence for a regular arrayed surface protein. Growth between 75 and $98^{\circ} \mathrm{C}$, $\mathrm{pH} 4 \cdot 5-7 \cdot 0$ and $1 \cdot 0-5 \cdot 0 \% \mathrm{NaCl}$; optima are $90^{\circ} \mathrm{C}, \mathrm{pH}$ 6 and $2 \% \mathrm{NaCl}$. Strictly anaerobic. Chemolithoautotrophic growth in the presence of $\mathrm{H}_{2}$ and $\mathrm{CO}_{2}$ with sulfur as electron acceptor. No chemo-organotrophic growth on meat extract, yeast extract, peptone, Casamino acids, gelatin, starch, formate, acetate or glucose. Sulfate, sulfite, thiosulfate, tetrathionate and nitrate are not used as electron acceptors. $\mathrm{H}_{2} \mathrm{~S}$ formed during growth. Growth stimulated by addition of $0 \cdot 1 \%$ meat extract, tryptone, gelatin or yeast extract. DNA base composition $45 \mathrm{~mol} \% \mathrm{G}+\mathrm{C}$. No significant DNA-DNA similarity to Ignicoccus islandicus. Type strain is isolate LPC $33^{\mathrm{T}}\left(=\mathrm{DSM} 13166^{\mathrm{T}}=\right.$ ATCC $700958^{\mathrm{T}}$ ), isolated from black smoker samples at $9^{\circ} \mathrm{N}, 104^{\circ} \mathrm{W}$ in the Pacific Ocean.

\section{ACKNOWLEDGEMENTS}

The excellent technical assistance of Kerstin Roth, Jutta Schipka and Peter Hummel is highly appreciated. We wish to thank Wolfgang Ludwig for providing the ARB program, Sabine Weber for primary work in electron microscopy,
Manfred Biebl for practical work on strain LPC37 and Agata Gambacorta for lipid analysis. This work was supported by grants of the Deutsche Forschungsgemeinschaft (STE 297/10-3) and the Fonds der Chemischen Industrie.

\section{REFERENCES}

Balch, W. E. \& Wolfe, R.S. (1976). New approach to the cultivation of methanogenic bacteria: 2-mercaptoethanesulfonic acid (HS-CoM)-dependent growth of Methanobacterium ruminantium in a pressurized atmosphere, Appl Environ Microbiol 32, 781-791.

Baumeister, W. \& Lembcke, G. (1992). Structural features of archaebacterial cell envelopes, $J$ Bioenerg Biomembr 24, 567-575.

Birnstiel, M. L., Sells, B. H. \& Purdom, I. F. (1972). Kinetic complexity of RNA molecules, J Mol Biol 63, 21-39.

Brenner, D. J. (1973). Desoxyribonucleic acid reassociation in the taxonomy of enteric bacteria, Int $J$ Syst Bacteriol 22, 298-307.

Brosius, J., Dull, T. J., Sleete, D. D. \& Noller, H. F. (1981). Gene organization and primary structure of a ribosomal RNA operon from Escherichia coli, J Mol Biol 148, 107-127.

Burggraf, S., Fricke, H., Neuner, A., Kristjansson, J., Rouvier, P., Mandelco, L., Woese, C. R. \& Stetter, K. O. (1990). Methanococcus igneus sp. nov., a novel hyperthermophilic methanogen from a shallow submarine hydrothermal system, Syst Appl Microbiol 13, 263-269.

Burggraf, S., Huber, H. \& Stetter, K. O. (1997). Reclassification of the crenarchaeal orders and families in accordance with $16 \mathrm{~S}$ ribosomal RNA sequence data, Int J Syst Bacteriol 47, 657-660.

Fricke, H., Giere, O., Stetter, K., Alfredsson, G. A., Kristjansson, J. K., Stoffers, P. \& Svavarsson, J. (1989). Hydrothermal vent communities at the shallow subpolar Mid-Atlantic ridge, Mar Biol 102, 425-429.

Gillespie, S. \& Gillespie, D. (1971). Ribonucleic aciddeoxyribonucleic acid hybridization in aqueous solutions and in solutions containing formamide, Biochem $J$ 125, 481-487.

Huber, H. \& Stetter, K. O. (1999). Crenarchaeota. In Embryonic Encyclopedia of Life Sciences. London: Nature Publishing Group.

Huber, H. \& Stetter, K. O. (2000). Order Desulfurococcales ord. nov. In Bergey's Manual of Systematic Bacteriology, 2nd edn, Vol. 1. New York: Springer (in press).

Huber, R., Burggraf, S., Mayer, T., Barns, S. M., Rossnagel, P. \& Stetter, K. O. (1995). Isolation of a hyperthermophilic archaeum predicted by in situ RNA analysis, Nature 376, 57-58.

Jannasch, H. W. \& Mottl, J. (1985). Geomicrobiology of deep-sea hydrothermal vents, Science 229, 717-725.

Marmur, J. \& Doty, P. (1961). Thermal renaturation of deoxyribonucleic acids, J Mol Biol 3, 585-594.

Marmur, J. \& Doty, P. (1962). Determination of the base composition of deoxyribonucleic acid from its thermal denaturation temperature, $J$ Mol Biol 5, 109-118.

Meyer, S. A. \& Schleifer, K. H. (1978). Deoxyribonucleic acid reassociation in the classification of coagulase-positive staphylococci, Arch Microbiol 117, 183-188.

Pley, U., Schipka, J., Gambacorta, A., Jannasch, H. W., Fricke, H., Rachel, R. \& Stetter, K. O. (1991). Pyrodictium abyssi, new species 
represents a novel heterotrophic marine archaeal hyperthermophile growing at $110^{\circ} \mathrm{C}$, Syst Appl Microbiol 14, 245-253.

Rieger, G., Müller, K., Hermann, R., Stetter, K. O. \& Rachel, R. (1997). Cultivation of hyperthermophilic archaea in cellulose capillaries resulting in improved preservation of fine structure, Arch Microbiol 168, 373-379.

Saiki, R. K., Scharf, S. J., Faloona, F., Mullis, K. B., Horn, G. T., Erlich, H. A. \& Arnheim, N. (1985). Enzymatic amplification of $\beta$ globin genomic sequences and restriction site analysis for diagnosis of sickle cell anemia, Science 230, 1350-1354.

Saiki, R. K., Gelfand, D. H., Stoffel, S., Scharf, S. J., Higuchi, R., Horn, G. T., Mullis, K. B. \& Erlich, H. A. (1988). Primer-directed enzymatic amplification of DNA with a thermostable DNA polymerase, Science 239, 487-491.

Stetter, K. O. (1988). Hyperthermophiles - physiology and enzymes, J Chem Tech Biotechnol 42, 315-317.

Stetter, K. O. (1996). Hyperthermophilic procaryotes, FEMS Microbiol Rev 18, 149-158.

Stetter, K. O., König, H. \& Stackebrandt, E. (1983). Pyrodictium gen. nov., a new genus of submarine disc-shaped sulphurreducing archaebacteria growing optimally at $105^{\circ} \mathrm{C}$, Syst Appl Microbiol 4, 535-551.

Trincone, A., Nicolaus, B., Palmieri, G., De Rosa, M., Huber, R., Huber, G., Stetter, K. O. \& Gambacorta, A. (1992). Distribution of complex and core lipids within new hyperthermophilic members of the Archaea domain, Syst Appl Microbiol 15, 11-17.

Völkl, P., Huber, R., Drobner, E., Rachel, R., Burggraf, S., Trincone, A. \& Stetter, K. O. (1993). Pyrobaculum aerophilum sp. nov., a novel nitrate-reducing hyperthermophilic archaeum, Appl Environ Microbiol 59, 2918-2926.

Wildgruber, G., Thomm, M., König, H., Ober, K., Ricchiuto, T. \& Stetter, K. O. (1982). Methanoplanus limicola, a plate-shaped methanogen, representing a novel family, the Methanoplanaceae, Arch Microbiol 132, 31-36.

Williams, W. J. (1979). Handbook of Anion Determination. London: Butterworths.

Woese, C. R., Kandler, O. \& Wheelis, M. L. (1990). Towards a natural system of organisms: proposal for the domains Archaea, Bacteria and Eucarya, Proc Natl Acad Sci USA 87, 4576-4579. 